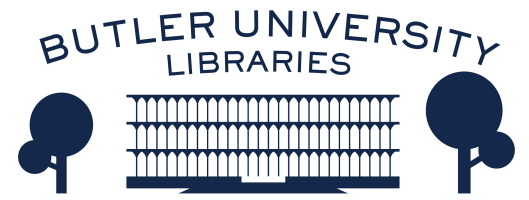

Journal of Hindu-Christian Studies

\title{
Buddha, Bhakti, and Brahman: Sebastian Kappen S.J.'s Dialogue with Indian Religions
}

\author{
Mathew Thekkemuriyil Antony \\ Missionary Congregation of the Blessed Sacrament \\ Idesbald Goddeeris \\ University of Leuven
}

Follow this and additional works at: https://digitalcommons.butler.edu/jhcs

Part of the Christianity Commons, Hindu Studies Commons, and the Religious Thought, Theology and Philosophy of Religion Commons

\section{Recommended Citation}

Thekkemuriyil Antony, Mathew and Goddeeris, Idesbald (2017) "Buddha, Bhakti, and Brahman: Sebastian Kappen S.J.'s Dialogue with Indian Religions," Journal of Hindu-Christian Studies: Vol. 30, Article 11.

Available at: https://doi.org/10.7825/2164-6279.1663

The Journal of Hindu-Christian Studies is a publication of the Society for Hindu-Christian Studies. The digital version is made available by Digital Commons @ Butler University. For questions about the Journal or the Society, please contact cbauman@butler.edu. For more information about Digital Commons @ Butler University, please contact digitalscholarship@butler.edu. 


\title{
Buddha, Bhakti, and Brahman: Sebastian Kappen S.J.'s Dialogue with Indian Religions
}

\author{
Mathew Thekkemuriyil Antony, MCBS \\ and Idesbald Goddeeris \\ University of Leuven
}

\begin{abstract}
This article analyzes how Sebastian Kappen S.J. (1924-1993), a social thinker and one of the most radical Indian liberation theologians, related to Indian religions. It argues that Kappen, in spite of his criticism of the caste system, also found inspiration in Hinduism. He especially appreciated the ontic and cosmic understandings of transcendence and immanence, the inclusive interpretation of the divine, and the religious approach to nature. In addition, Kappen also valued other Asian religious traditions, such as Buddhism and the Bhakti movement. Being an anti-institutional and anti-hierarchical progressive theologian,
\end{abstract}

Kappen used Indian religions as a challenge to his own Christian faith.

Sebastian Kappen (1924-1993) was an Indian liberation theologian and social thinker who has been eclipsed by other progressive theologians from India, such as M.M. Thomas and Samuel Rayan, though he was certainly as important, and maybe even more pioneering. Kappen is especially reputed for his book Jesus and Freedom (1977), which in 1980 was censored by the Congregation for the Doctrine of the Faith because it challenged Jesus' godhood and accused the Church of giving too much weight to cult and institutions. ${ }^{1}$ Kappen, however, also

Mathew Thekkemuriyil Antony is a Catholic priest from Kerala, India, belonging to the Missionary Congregation of the Blessed Sacrament (MCBS). He earned a B.A. from Bangalore University and a B.Th. from Paurastya Vidhyapitham in Kottayam. Later, he secured an MPhil in Religious and Cultural Studies (KU Leuven, Belgium). He is also a visiting lecturer at Sanathana Divyakarunya Vidyapitham, the theological seminary of the MCBS. He is currently preparing a doctoral dissertation on Sebastian Kappen S.J. Email: sthekkemuriyilmcbs@gmail.com

Prof. Dr. Idesbald Goddeeris is a professor of History and teaches, inter alia, History of European Colonization and History of India. He has worked extensively on global social movements and on postcolonial memories and recently published in Journal of Migration History (2017), Postcolonial Studies (2016), Interventions: International Journal of Postcolonial Studies (2015), and Journal of Contemporary History (2015). He is now embarking on a new project, supervising several dissertations on postcolonial missionaries and Indian Jesuits. Email: idesbald.goddeeris@kuleuven.be 
had original thoughts about Indian religions, specifically Buddhism, the Bhakti movements, and Hinduism. This article will demonstrate that Kappen used Indian religious traditions to both criticize and challenge the Christian Church in India.

\section{A short biography}

Kappen underwent several transitions in his life. ${ }^{2}$ He was born to a Syrian Catholic family and joined the Society of Jesus in 1944 . He went on to train in Calicut, Kodaikanal, Mangalore, and Pune, and was ordained a priest in 1957. Two years later, the Society of Jesus sent him to the Gregorian University in Rome, where under the guidance of Joseph de Finance (1904-2000) he wrote a dissertation titled Praxis and the emancipation of Man from Religious Alienation according to the Economical and Philosophical Manuscripts of Karl Marx (1961). This was the start of a long fascination with Marxism. Kappen returned to India in 1962 and from the early 1970s began publishing on capitalism and alienation, inter alia From Faith to Revolution (1972), Marxian Atheism (1983), and Liberation Theology and Marxism (1986). In 1975 he moved to Madras, where he lived among the poor of a slum, isolated from the Jesuit institution. Kappen founded the Centre for Social Reconstruction (1976) and the journals Anawim (1976-1984) and Socialist Perspectives (1978-1982).

By then he had also shifted to a new subject, namely Christology. His ground-breaking book Jesus and Freedom (1977) led to a conflict with the Vatican in the early 1980s. ${ }^{3}$ Kappen had aired a great deal of criticism toward much of the institutionalization and hierarchy in the church. He called for a return to the original message of Jesus, juxtaposing the human and historical Jesus with the Christ of faith, which he considered to be a construct of the Church created over the centuries. Initially, his book did not provoke much reaction, but in 1980 the Congregation for the Doctrine of the Faith censored the book. This is not surprising: the Vatican had embarked on a campaign against progressive theology. It accused Kappen of unorthodox Christology and of assimilation of Marxist ideology. Over the following months, the Jesuit authorities, including the Superior General Pedro Arrupe, mediated between Kappen and the Holy See, but the former held his ground, and in 1982 the Congregation for the Doctrine of the Faith ended the disciplinary action. ${ }^{4}$

From the early 1980s onwards, Kappen also wrote on Indian religions. ${ }^{5}$ He initially focused on Hinduism, which he criticized for a variety of reasons. First and foremost, he rejected the caste system and the oppression, discrimination, and exploitation that it encompassed. Arguing that social hierarchy should be based on merit, he called on progressive thinkers, including Christian and Hindu theologians, to help the marginalized escape the false convictions that the dominant class had instilled. ${ }^{6}$ Kappen also targeted Hindu priests. He not only denounced their monopolization of rituals, but also their political influence and economic wealth, which had grown historically but had not, in contrast to what took place in the Western world, been challenged by revolts. ${ }^{7}$ In reference to Buddha's criticism of sacrifices and priestly intermediaries, he thought that sages should possess philosophical knowledge rather than a mastery over rituals. ${ }^{8}$

Though Kappen was critical of Indian religious traditions, he also strived to integrate their progressive and liberating elements. This 
article will examine which elements attracted him, how he made use of them, and how he facilitated a dialogue between these Indian religious traditions and Christianity. Primarily based on Kappen's writings, the article begins with his views on Buddha, proceeds with his interpretation of Bhakti, and ends with his assimilation of Hinduism.

\section{Buddha}

Just as many of his contemporaries, Kappen applauded Buddhism. First and foremost, he emphasized that Buddha considered metaphysical questions irrelevant since they were about the attributes and the nature of the absolute Other and were far from the bare human life on earth. Buddha did not want to conceptualize everything but rather looked for practical solutions, such as found in the Eightfold Path. Buddha also was preoccupied with morality, which he believed stemmed from compassion and love. His approach was inclusive - encompassing universal kinship, and not only family, clan, or caste $-^{9}$ and anthropocentric - proposing a shift from the religiosity of man-nature encounters to interhuman encounters. ${ }^{10}$ Kappen stressed that Buddha did not speak of rituals, sacrifices, priests and gods, and accordingly inaugurated a new era of human ethical civilization. ${ }^{11}$

Kappen not only appreciated Buddha as a prophet of universal love and ethical religiosity, but also highlighted the transformative elements within Buddhism. Not surprisingly, he mentioned Buddha's protest against the deprivations of man, which were caused by the craving for material things and pleasures that would ultimately generate sorrow. ${ }^{12}$ But Kappen found even more relevance in Buddha's discourse on the economic roots of violence.
Buddha lived in an age that witnessed commercial growth and welcomed individualism, competition, profiteering, and cheating in business. Buddha's social teaching clearly explicated the dignity of work and service, and demanded rightful earning of wealth. Furthermore, Buddha instructed employers to take into account the health of their employees by providing them proper food and wage, treating their illnesses, and granting leave. He aimed toward a morality (dharma) that would consider everyone equal and would replace laws without spirit. A state with such morality could surpass religious nationalism and even create a stateless society. ${ }^{13}$

Kappen's exploration of the liberating and humanizing elements in Buddhism was not coincidental: he considered them significant in contemporary India. He found Buddha's proposal of a casteless anthropocentric society of universal kinship and love, free of religious and priestly dominance, appealing. $\mathrm{He}$ considered Buddha prophetic in his approach to all forms of religious and social oppression, and emphasized that Buddha wanted to bring the people back from the clutches of myths to reason, from the altar to the worksite, from gods to fellow humans. ${ }^{14}$ According to Kappen, Buddha was a true revolutionary since he questioned the existing religious and social taboos, denounced metaphysical views, and dealt with the alienated existence of human beings.

\section{Bhakti}

Kappen also searched for liberating and humanizing factors in the Bhakti movement. This was a Hindu religious movement that originated in the $7^{\text {th }}$ century C.E. in south India, and in the following centuries spread to north 
and east India, remaining significant until the $15^{\text {th }}$ century. ${ }^{15}$ Bhakti is an umbrella for various forms of theistic devotional trends. Some of them are mainly centered around one god or goddess, but others have additional deities. Most important is the individual and single-minded devotion of the bhakta (devotee) who practices bhakti (devotion) to attain liberation. This liberation was first and foremost spiritual: personal devotion would contribute to liberation from the five human senses, which were believed to lead to one's slavery to the material world. ${ }^{16}$

Kappen, however, emphasized the social aspects of this liberation. He considered the Bhakti movement to be an emotional and religious cult against the path of knowledge (jnana). This path was only accessible to the upper castes. ${ }^{17}$ Most of the movement's saints and poets were from lower castes and proudly acknowledged this, simultaneously claiming to have been liberated. ${ }^{18}$ They condemned ritual observances and the caste system, and wrote in vernacular languages in protest against Sanskrit, the language of the elites. Moreover, they chose disciples from among the lower castes and Dalits and did not distinguish between devotees on the basis of caste or gender. ${ }^{19}$ All of this appealed to Kappen. He presented the Bhakti movement as revolutionary and provocative, especially because a bhakta's access to the divine was unconditional. Birth, social status, sex, wealth, caste, color, etc., were not counted in the deitydevotee encounter. If God had any partiality, it was for the poor and the marginalized, not for the rich. ${ }^{20}$

Yet Kappen was also critical of the movement. Unlike Buddhism, he stated, Bhakti did not struggle to eradicate castes: the major
Bhakti scripture - the Bhagavata Purana - did not denounce the caste system. Moreover, Kappen noted, the Bhakti movement did not seem to have directly challenged the existing structural evil. Instead, bhaktas believed that devotion (mostly emotional) would disregard and overtake the caste and class divisions via its uniting factor of love. ${ }^{21}$

Kappen also reflected on the appropriation of the Bhakti movement. Most of the bhaktas did not write down their poems or thoughts. Traveling from place to place, they went on singing and teaching. Their poems were for a long time orally transmitted before being written down by others. He felt this interval was cause for doubt on the authenticity of their message. It seemed that many poems and songs were Brahminized in the process. Higher castes appropriated low caste, untouchable, and Muslim Bhakti saints. ${ }^{22}$ According to Kappen, the domestication of the Bhakti saints and their teachings by the Hindu orthodoxy was one of the major causes of the weakening of the movement. Many Bhakti sects became alienated from their original form and goal. ${ }^{23}$

\section{Influences}

Of course, Kappen was not the only one who dealt with these issues. The caste system and the Brahminic priestly hegemony had been criticized for decades by many social and religious reformers. Indian liberation theologians followed suit. The first one was M.M. Thomas (1916-1996), a Keralite theologian and social activist who served as the Chairperson of the Central Committee of World Council of Churches (1968-1975). ${ }^{24}$ Yet Dalit liberation theologians dismissed Thomas for the absence of outright condemnation of the caste system in his works. They called him a caste 
104 Mathew Thekkemuriyil Antony and Idesbald Goddeeris

Christian (Thomas belonged to the Syrian Christians, who are said to be upper caste converts) and a theologian with a Brahminical mindset. ${ }^{25}$ Kappen, who also had a Syrian background, did not receive such critiques.

Other liberation theologians condemned the caste system just as thoroughly as Kappen. The Tamil Jesuit Michael Amaladoss (1936-) denounced hierarchy and exclusion as two major characteristics of the Indian caste system. ${ }^{26}$ The Keralite Jesuit Samuel Rayan (1920-) called caste a "powerful, divisive, and oppressive institution." He found it imperative to tackle caste discrimination and criticized churches in India that had accommodated the caste system: for Rayan, the system was a mockery of the gospel. ${ }^{27}$

Kappen did not differ greatly in his critique of caste, but distinguished himself with his attention to Bhakti and Buddhism. Other Indian liberation theologians had a more peripheral approach, and primarily used Buddhism in order to strengthen Christianity in India. Samuel Rayan, for instance, appreciated the spiritual heritage of Buddhism and called for the acknowledgement of other Indian religions' significance as well as the promotion of creative dialogues with other faiths and ideologies. ${ }^{28}$ However, Rayan did so in order to rethink the mission of the Church in India and to learn how the church could grow in India by adapting constructive elements in the Indian spiritual heritage. A similar position can be found with M.M. Thomas. He also wanted to strengthen the renewal of the Church in India by acknowledging other religions, but he remained Christocentric and found the cross of Christ capable of transcending the issue of religious pluralism. Thomas even explicitly stood against Kappen and refuted any form of assimilation of the ideologies of one religion by another. ${ }^{29}$ Kappen, conversely, always promoted the concept of syncretism, just as some Hindu scholars envisioned decades back. ${ }^{30}$

If anyone resembled and inspired Kappen, it was the Belgian Catholic priest and Marxist sociologist François Houtart (1925-2017). Houtart closely collaborated with Latin American liberation theologians, but because of his connection with the anti-war Communist movement was banned by the Vatican from helping to prepare the 1968 Bishops Conference at Medellin. Instead, Houtart accepted an invitation from the Sri Lankan liberation theologian Tissa Balasuriya (1924-2013) and went to Colombo. On his way, he visited Kerala, where he met Kappen. This was the start of a close collaboration. Kappen returned the visit in February 1970, staying for six weeks as a guest professor of ecclesiology at the Centre for SocioReligious Research at the Université Catholique de Louvain. He must have been inspired by Houtart's adherence to Marxism and in the early 1970s, after an eight year break following his doctoral defense, began publishing intensively on Marx's understanding of capitalism, alienation, and revolution. ${ }^{31}$ In 1977 Houtart wrote an introduction to one of Kappen's key works, Jesus and Freedom.

Houtart not only fueled Kappen's interest in Marx but also drew his attention to Buddha. Houtart himself completed his doctoral studies in Buddhism in 1974 and later continued working alongside Sri Lankan theologians fostering the Buddhist-Christian relationship. Along with Tissa Balasuriya, the co-founder of the Centre for Society and Religion (1971), Aloysius Pieris (1934-) in particular should be mentioned here. As the founder of the Center for Encounter and Dialogue (1974), Pieris notably 
acknowledged the contributions of Indian progressive Christian theologians in the exploration of Buddhism. ${ }^{32}$

\section{Kappen's positive view of Hinduism}

Kappen was critical of Hinduism, though he also found inspiration in it. He emphasized the ontic character of Hinduism, which saw God as "one with the world of names and forms" ${ }^{33}$ In other words, he considered Hinduism as a cosmic religiosity, in which God is both transcendent and immanent, i.e. God is simultaneously far removed from and close at hand 'in' nature (or even 'is' nature). Like Hindus, Kappen also believed that the absolute Other (God) underwent a process of becoming, in and through nature. ${ }^{34}$

A second inspiring aspect of the Hindu tradition for Kappen was the attempt to discover the divine within oneself by means of yogic practices. Hinduism saw the Self (Brahman) within and beneath the human self (atman). Different spiritual activities, such as yoga, helped a person to illumine the Brahman within. By harnessing the self and the Self (atman and Brahman), a person gradually withdrew from the world of senses, actions, and passions. Kappen fully endorsed this humanizing process that "sought to create the fully integrated man." 35

Kappen's third constructive observation about Hinduism was its attitude regarding nature. People could see nature from two perspectives: pragmatic and religious. Kappen emphasized that the traditional Indian mind looked at nature from a religious angle. $\mathrm{He}$ stressed that in Hindu culture, "nature is not something to be conquered or manipulated", ${ }^{36}$ but that it is the womb of everything, the source of fertility, and therefore, the mother of all creation. For this reason, there was a sense of kinship between nature and man. Kappen referred to the Abhijñannaśäkuntalam to elucidate this. This is a renowned Sanskrit play by Kālidāsa, a classical Sanskrit writer who lived around the $5^{\text {th }}$ century CE. It was an expansion of a story in the Mahäbhärata, one of the two great epics of ancient India, and described the heroine Shakuntala's farewell to the plants and animals of the hermitage where she had grown up. The piece taught the art of living and called for communion with nature. It viewed nature as a self-revelation of the divine and expressed the thought that every creature bore the mark of the divine. Kappen subscribed to these ideas wholly and in his 1991 article called the earth the 'Mother Goddess.' ${ }^{37}$

Kappen contrasted these elements of Hinduism against Christianity, which, he emphasized, gave priority to the ethical understanding of the transcendence and immanence of God. Transcendentally, Christians considered God to be the absolute Other from all evils; immanently, He was in the world to lead the creation to fullness and freedom. Kappen called for a more Hindu understanding of immanence, criticizing Semitic religions for seeking the divine outside oneself and for considering it the absolute Other.

In a certain sense, Kappen exaggerated the juxtaposition between Hinduism and Christianity. He stressed that the Bible considers the earth as something to dominate and subdue. This is not an isolated view, given some quotes from Genesis, such as "and let them have dominion over the fish of the sea, and over the birds of the air, and over the cattle, and over all the wild animals of the earth, and over every creeping thing that creeps upon the earth" $(1$, 26) and "be fruitful and multiply, and fill the earth and subdue it" $(1,28){ }^{38}$ However, not all 
Christian theologians share this interpretation (and the contrast with Hinduism), arguing that the dominion over the earth is not to destroy it but to guard and protect it.

Kappen's exaggeration can also be seen in his understanding of the presence of God in nature. He emphasizes Christianity's understanding as the absolute otherness of the Other, who is only ethically related to nature. Yet Christianity also had, to a certain extent, an ontic interpretation of immanence. Psalm 139, for instance, states that man cannot escape the presence of God in nature. Nevertheless, one cannot ignore the differences between Christianity and Hinduism in this field. Although the Bible spoke of the presence of God among his people, the word of God becoming flesh, and God taking the form of man, ${ }^{39}$ the transcendental God was dwelling among his people, but was not part of nature. Kappen highlighted these differences. It is to his credit that he, as one of the very few Christian theologians in India, dared to hold the Hindu understanding of immanence. Others likely avoided the risk of pantheism, which saw nature and everything in it as God and/or ways to God. ${ }^{40}$

\section{Conclusion}

Kappen's appreciation of certain Hindu concepts did not mean that he felt entirely positive about Hinduism. On the contrary, he criticized Hinduism for legitimating, sanctioning, and maintaining oppression and discrimination. He primarily attacked the Hindu caste system, the hegemony of the priestly class, and the scriptures. Importantly, his criticism of Hinduism was greater than his appreciation and

\section{Notes}

${ }^{1}$ Kappen, Jesus and Freedom (Maryknoll: Orbis Books, 1977), 21-2. went beyond the topics discussed in this article. For instance, Kappen also regularly expressed his concern over Hindutva, which he identified with German Nazism. ${ }^{41}$

Kappen used other Indian religions as tools in attacking Hindu practices. He highly valued Buddha's ideology of a casteless and anthropocentric society of universal kinship and love, free of religious and priestly dominance. Similarly, he was attracted to the Bhakti movement because of its opposition to the prevalent Brahminical hierarchical system, ritualistic ceremonies, and idol worship.

However, this criticism of Hinduism did not mean that he completely rejected Hindu beliefs. Kappen appreciated certain aspects, such as the ontic and cosmic understanding of transcendence and immanence, the inclusive interpretation of the divine, and the religious approach to nature. Being an anti-institutional and anti-hierarchical progressive theologian, Kappen used Hinduism as a challenge to his own Christian faith.

Kappen was convinced that a proper dialogue between the Indian religious tradition and Christianity would enrich the latter. His understanding of Indian religious tradition can thus further strengthen Hindu-Christian relations. In a pluralist society, religions cannot be in isolation but have to assimilate with each other. Kappen's open and balanced criticism and dialogue with Indian religious tradition, therefore, still today poses a challenge to religions in India.

\footnotetext{
${ }^{2}$ Interview with the Jesuit theologian Sebastian Painadath at Ernakulam in Kerala on 15 September
} 
2014. For more details, cf. Ajit Muricken, "S. Kappen: the Man and his Contribution to the study of Counter-culture," in Religion, Ideology and Counterculture, eds. Philip Mathew and Ajit Muricken (Bangalore: Horizon Books, 1987), 9-31; S. Painadath, Preface to Jesus and Culture: Selected Writings of Sebastian Kappen, S.J., by S. Kappen (New Delhi: ISPCK, 2002), vii-xiv; L. Jayaseelan, Towards a Counter-culture: Sebastian Kappen's Contribution (New Delhi: ISPCK, 1999); and Introduction to Towards a Holistic Cultural Paradigm, edited by Sebastian Vattamattam (Thiruvalla: CSS Books, 2003), 11-26.

${ }^{3}$ The complete story, based on material from the archives of the Jesuit Provincial House at Calicut, will be extensively discussed in the forthcoming doctoral dissertation of Mathew Thekkemuriyil Antony, Constructing Counter-culture through Theology of Liberation: An Intellectual Biography of Sebastian Kappen SJ (KU Leuven, 2017-18, supervisor Prof. Dr. I. Goddeeris, co-supervisor Prof. Dr. J. De Maeyer).

${ }^{4}$ The dispute thus ended differently than it did with Tissa Balasuriya and Michael Amaladoss, two other South Asian theologians who clashed with the Vatican. Balasuriya was a Sri Lankan progressive theologian who was excommunicated by the Vatican in 1997 for doctrinal errors in his writings. Amaladoss, an Indian Jesuit, was warned by the Vatican in 2014. In both cases, the accused recanted their controversial statements. Balasuriya's excommunication was revoked in 1998. See: Gerard Sloyan, "Vatican excommunicates progressive theologian: the base of the censure." https://astro.temple.edu/ arcc/tissa.htm (accessed 28 August 2017) and Balasuriya, "Excommunication and Liberation," in From Inquisition to Freedom: Seven prominent Catholics and their struggle with the Vatican, ed. Paul Collins (London: Continuum, 2001), 80-108.

${ }^{5}$ One of the first works was his article "The Present Cultural Crisis: Analysis and Prognosis", which he published in his journal Socialist Perspectives in 1980. A second article with reference to Hinduism came out under the title "Jesus in the Indian Context", which originally was a paper that he presented at the seminar on "The Significance of Jesus for Asia”, held in Vidya Jyoti, New Delhi, in April
1982.These two articles were followed by his book Jesus and Cultural Revolution: An Asian Perspective in 1983. Towards the end of his life, Kappen wrote some more extensive texts, which post-mortem appeared in his Hindutva and Indian Religious Traditions (2000).

${ }^{6}$ S. Kappen, Tradition, Modernity, and Counter culture: an Asian Perspective (Bangalore: Visthar, 1993), 4 and S. Kappen, "Orientation for an Asian Theology," in Asia's Struggle for Full Humanity: Towards a Relevant Theology, Papers from the Asian Theological Conference, January 7-20, Wennappuva, Sri Lanka 1979, ed. Virginia Fabella (Maryknoll: Orbis Books, 1980), 118.

${ }^{7}$ Kappen, Hindutva and Indian Religious Traditions, 40.

${ }^{8}$ Kappen, Jesus and Culture, 31.

${ }^{9}$ Kappen, Jesus and Culture, 33.

${ }^{10}$ Kappen, Jesus and Culture, 34.

${ }^{11}$ For more details, cf. S. Kappen, "The Materialistic Conception of History and the Indian Religious Tradition," Negations 8 (Oct-Dec, 1983): 4-6.

${ }^{12}$ L. Jayaseelan, Towards a Counter-Culture: Sebastian Kappen's Contribution (Delhi: ISPCK, 1999), 39.

${ }^{13}$ Ajith Muricken, "S. Kappen: the Man and his Contribution to the Study of Counter-Culture," Religion, Ideology and Counter-Culture: Essays in honour of S. Kappen, eds. Philip Mathew and Ajith Muricken (Bangalore: Horizon Books, 1987), 17.

${ }^{14}$ Jayaseelan, Towards a Counter-Culture, 39.

${ }^{15}$ Ainslee T. Ambree, ed. Encyclopaedia of Ancient History (London: Macmillan, 1988), 539.

${ }^{16}$ Winand M. Callewaert, The Hagiographies of Anantdas: The Bhakti Poets of North India (London and New York: Routledge Curzon, 2000), 12; John Stratton Hawley, "Author and Authority in the Bhakti Poetry of North India," The Journal of Asian Studies 47, no. 2 (May, 1988): 272-3; K. Pechilis Prentiss, The embodiment of Bhakti (New York: Oxford University Press, 1999), 134-5; N.N. Battacharya, ed. Medieval Bhakti Movements in India (New Delhi: Munishiram Manoharlal, 1989); Diana Eck and Francoise Mallison, Devotion Divine: Bhakti Traditions from the Regions of India (Paris: Ecole Francaise D’Extreme-Orient, 1991.

${ }^{17}$ Kappen, "The Materialistic Conception of History and the Indian Religious Tradition," 6-7. 
108 Mathew Thekkemuriyil Antony and Idesbald Goddeeris

${ }^{18}$ See, inter alia, John Stratton Hawley, "Author and Authority in the Bhakti Poetry of North India," The Journal of Asian Studies 47, no. 2 (May, 1988): 286 and Winand M. Callewaert and Peter G. Friedlander, The Life and Works of Raidas (New Delhi: Monohar, 1992), 22.

${ }^{19}$ Karine Schomer and W.H. McLeod, eds. The Sants: Studies in a Devotional Tradition in India(New Delhi: Motilal Banarsidass, 1987), 2.

${ }^{20}$ Kappen, "The Materialistic Conception of History and the Indian Religious Tradition," 7.

${ }^{21}$ Ibidem. For more details, cf. Richard Fox Young, "Can Christians Be Bhaktas? A Sanskritic View from Central India, c. 1850," Journal of HinduChristian Studies 21 (2008): 59.

${ }^{22}$ Callewaert, The Millenium Kabir Vani: A Collection of Pad-s, 2 and Narinder Mohkamsing, "Machiavellian Hindutva Untamed," Totalitarian Movements and Political Religions 11, no. 1 (March 2010): 105.

${ }^{23}$ Kappen, Jesus and Cultural Revolution, 45.

${ }^{24}$ Paul Abrecht, "M.M. Thomas and Paulos Mar Gregorios," in M.M. Thomas: The Man and His Legacy, ed. Jesudas M. Athyal (Thiruvalla: The Thiruvalla Ecumenical Charitable Trust, 1997), 22.

${ }^{25}$ Adrian Bird, M.M. Thomas: Theological Signposts for the Emergence of Dalit Theology (PhD. diss., Edinburg University, 2008), 106.

${ }^{26}$ Michael Amaladoss, A Call to Community: The Caste System and Christian Responsibility (Gujarat: Gujarat Sahitya Prakash, 1994), xi. For more details, also cf. Chanseok Lee, The Christological Perspectives in the Theologies of Raymon Panikkar and Byungmu Ahn: Toward an Asian Christology, (PhD. diss., Drew University, Madison, NJ, 2005), 116-122.

${ }^{27}$ Samuel Rayan, “Editorial: On Caste," Jeevadhara 11 (1981): 220 and Samuel Rayan, "Theological Priorities in India," in Irruption of the Third World: Challenge to Theology, eds. Virginia Fabella and S. Torres (Maryknoll, NY: Orbis Books, 1983), 30-41 (quotation p. 33).

${ }^{28}$ Diane W. Ferm, Profiles in Liberation: 36 Portraits of Third World Theologians (Mystic: Twenty-Third Publications, 1988), 103 and Samuel Rayan, "Inculturation and the Local Church," Mission Studies 3, no. 1 (1986): 15.
${ }^{29}$ M.M. Thomas, Man and the Universe of Faiths (Madras: Christian Literature Society, 1975), 149-50.

${ }^{30}$ For more details, cf. Klaus K. Klostermaier, "A Literary Hindu-Christian Dialogue a Century Ago: Still Actual?" Journal of Hindu-Christian Studies 24

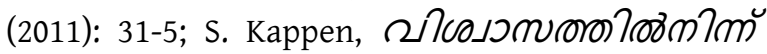

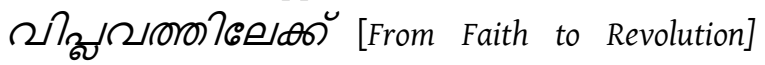
(Kottayam: National Books, 1972), 102-3.

${ }^{31}$ These concepts first appeared in articles in the journals like Jeevadhara and Religion and Society, including "The Christian and the Call to Revolution" (1971) and "The Goals of Revolution" (1973). But they were also further elaborated in books, which were written all along the 1970s and 1980s: From Faith to Revolution (1972), Marxian Atheism (1983), and Liberation Theology and Marxism (1986).

${ }^{32}$ Cf. Aloysius Pieris, Love Meets Wisdom: A Christian Experience of Buddhism (Maryknoll, NY: Orbis, 1988), 86-7, 106, and 128.

${ }^{33}$ Kappen, Jesus and Cultural Revolution, 67.

${ }^{34}$ Ibidem.

${ }^{35}$ Kappen, Jesus and Cultural Revolution, 68.

${ }^{36}$ Kappen, Jesus and Cultural Revolution, 69.

${ }^{37}$ Rig Veda, Book I, Hymn CLXIV, 33.

${ }^{38}$ Lynn White, "The Historical Roots of our Ecologic Crisis," Science 155 (1967): 1203-7 and Paul R. Ehrlich, The Population Explosion (London: Arrow Books, 1991).

${ }^{39}$ Jn 1, 14; Phil 2, 6; Eph 4, 6.

${ }^{40}$ For a clear distinction between the religions of one notion of truth, one man, and one text and the Hindu thought of pluralism, cf. Ankur Barua, "Hindu Responses to Religious Diversity and the Nature of Post-mortem Progress," Journal of Hindu-Christian Studies 27 (2014):78.

${ }^{41}$ E.g. in Jesus and Cultural Revolution: An Asian Perspective (1983). Ten years later, he produced an article dealing with the issue, namely "Hindutva, Emerging Fascism?," which originally appeared in Understanding Communalism, eds. M. Muraleedharan, P.K. Michael Tharakan, and Sebastian Kappen (Bangalore: Visthar, 1993) and then in Hindutva and Indian Religious Traditions (2000). 